\title{
Impact of behavioral factors towards the adoption of mobile learning among higher education students in public and private universities: A pitch
}

\author{
Haroon Iqbal ${ }^{a, 1}$ and Hafiz A hmad Ashraf ${ }^{\text {a }}$ \\ a University of the Punjab, Gujranwala Campus, Pakistan
}

\begin{abstract}
A bstract: This pitch research letter (PRL) applies the pitch template developed by Faff $(2015,2017)$ to an academic project on the impact of behavioral factors towards the adoption of mobile leaming among higher education students in public and private universities of Pakistan. This template is hel pful in identifying the core elements of the proposed research project. This PRL consists of a brief introduction about the pitch, followed by a brief commentary on the pitch and personal reflections of the pitcher on the pitch exercise itself.
\end{abstract}

K eywords: Pitching research, Mobile learning, Higher education, Pakistan

\section{J EL codes: 123}

\section{Introduction}

This pitch research letter (PRL) applies the pitch template developed by Faff $(2015,2017)$ to an academic project; that is, the impact of behavioral factors towards the adoption of mobile learning in public and private universities of Pakistan. I started my MBA (Hons) in 2015 in marketing specialization after the completion of BBA (Hons) with the same special ization. During the first semester of my MBA study, my course instructor Mr. Hafiz Ahmad Ashraf (second author)

1 Corresponding authors: Department of Business Administration, University of the Punjab, Gujranwala Campus near Alipur Chowk, Gujranwala, Punjab, Pakistan; tel. (+92)3213785994; email addresses: haroon.chohan39@gmail.com, ucpahmad@gmail.com 
encouraged me to plan research work on the topic "the impact of behavioral factors towards the adoption of mobi le learning among hi gher education students studying in public and private universities of Pakistan." I started working on that research paper. At that time my supervisor/instructor advised me that according to Faff (2015), there are two difficult challenges in every research project: starting and finishing. Before starting the research, my experience was just as Faff (2015) warned. As I had never completed a research paper before, it was a quiet new task for me. My supervisor provided me guidance at every step where I needed. Also, he urged me to take guidance from the work done by Professor Faff. These things helped me throughout the process and my whole work was accomplished successfully.

After the completion of my MBA research project, my supervisor advised me to work on research pitch. I started my work on the research pitch on $15^{\text {th }} \mathrm{J}$ une 2016 and it completed on $10^{\text {th }} \mathrm{J}$ uly 2016. During this work, I got help from discussions with supervisor and he guided me to get further hel $p$ from the readings on pitching research (Faff, 2015; 2017). In the beginning it looks difficult because my understanding of the pitching research concept was not dear. But as I thoroughly studied the author's guidelines and I discussed it with my supervisor; he gui ded me to start work in each of the sections carefully and separately. It was not possible to write all the sections in one sitting, firstly I wrote the main theme of every section then after the completion of writing all the themes of the pitch, I started writing every section in detail. After writing in detail, again there was a need to go through the work so I refined the whole writing again and improved the identified weaknesses as best I could.

The structure of this pitching research letter is as follows. In the second section there is a brief commentary on the pitch I completed. In third section, there are my personal reflections regarding the research pitching exercise. This paper ends with a conclusion.

\section{Commentary}

Table 1 displays my research pitch on the topic of "impact of behavioural factors towards the adoption of mobile leaming among higher education students in public and private universities of Pakistan" (Item A). Item B is the primary research question which is "does the perceived ease of use, perceived usefulness and attention to adopt mobile learning have a positive impact on behavioural intention to adopt mobile learning?" Item C consists of three research papers which are related to my research work. 
Table 1. Completed 2 page research pitch template on adoption of mobile learning

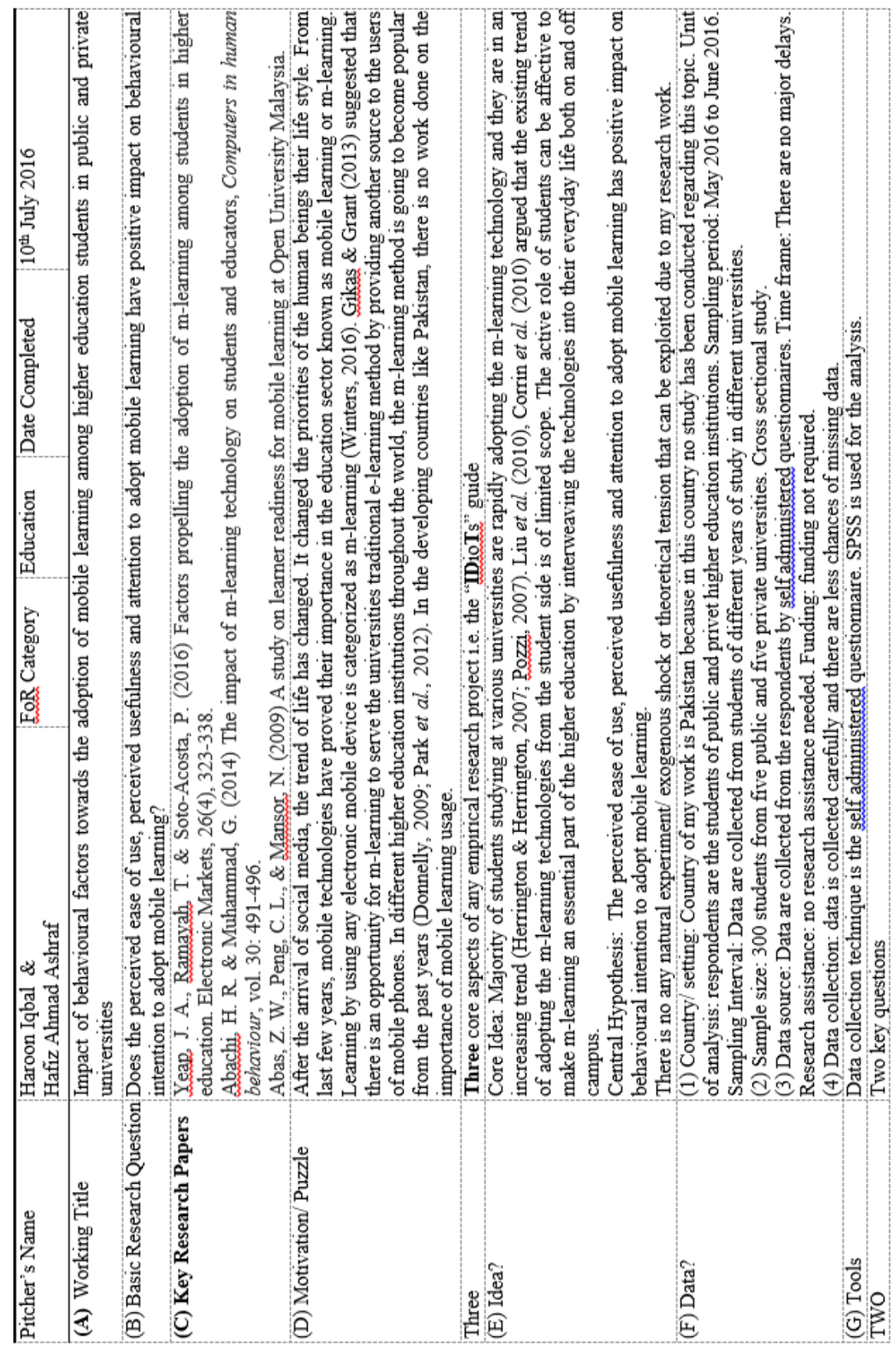




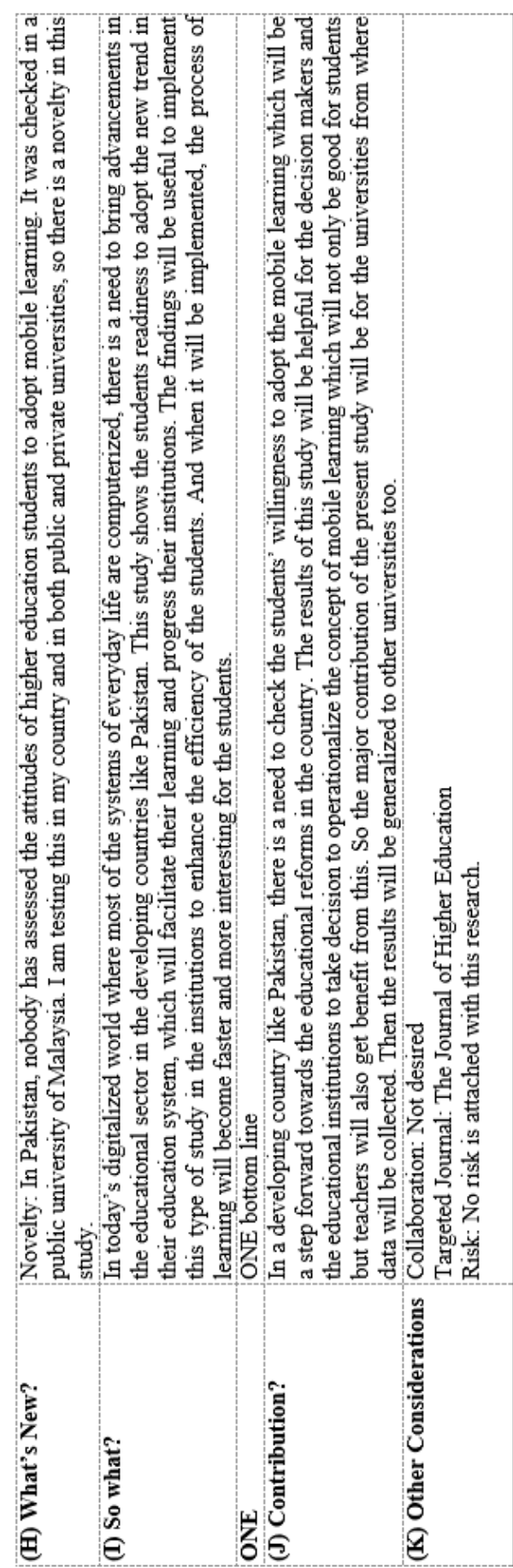

Vol. 16, No. 3 


\section{Personal reflection on the pitch exercise}

According to Faff (2017: 1) the biggest challenge in research is to start - and to start well and confidently. I agree. How can we determine that the topic which is to be selected by the researcher is really a gap which should be covered? A researcher can't adopt the right direction for the research if he/she is not willing to spend much of his/her time to study the literature.

My research supervisor (Prof. Hafiz Ahmad Ashraf) arranged a seminar and invited a foreign PhD scholar (Mr. Searat Ali, a PhD student at the time) as a guest speaker. Mr. Seerat Ali introduced the research pitching idea to us and provided the detail led information about the benefits and advantages of pitching research. I found that the research pitch guides the researcher, particularly regarding the research alignment and direction. Furthermore, it provided me knowledge that how can I present my research to the targeted audience.

The Mickey Mouse diagram is very effective and simple diagram to demonstrate the overall research plan and impact of its outcomes. Figure 1 indicates the Mickey Mouse diagram applied to my research work.

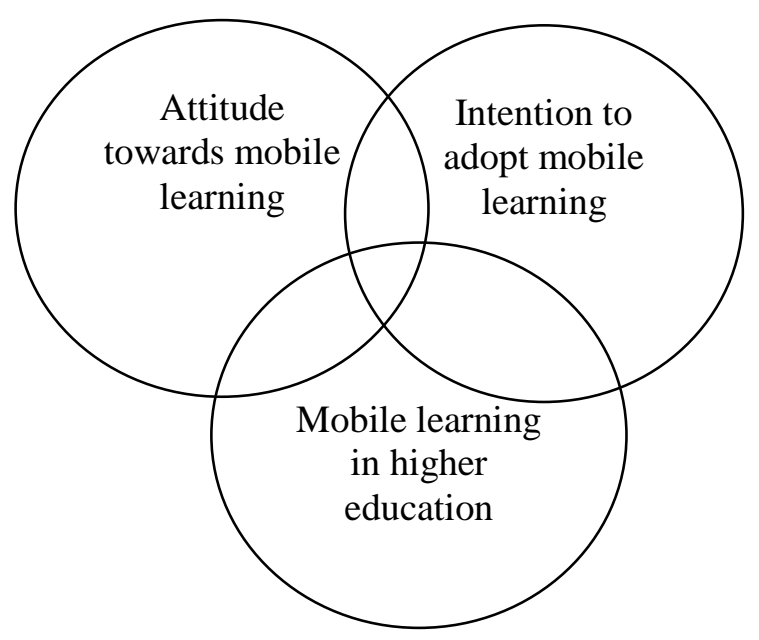

Figure 1. Mickey M ouse diagram illustrating the novelty of a research idea

\section{Conclusion}

Based on Faff's (2017) guidelines, this PRL covers the basic pitch for a proposed research project on the impact of behavioural factors towards the adoption of mobile learning among higher education students in public and private universities 
of Pakistan. In the process of doing work on my research pitch I realize Faff's (2017) pitch template is very useful for novice researchers. Supervisors do not have time to read the many pages of a detail led research proposal. The pitching approach is beneficial for the researcher, to organise and align his/her research in very structured way.

\section{Acknowledgments}

We would like to warmly acknowl edge the efforts and cooperation of the reviewer and editor of the journal for their extensive support and feedback provided during the review process of this PRL. Any remaining infelicities belong to the authors.

\section{R eferences}

Abachi, H.R. \& Ghulam, M. (2014) "The impact of m-learning technology on students and educators", Computers in Human Behaviour, vol. 30: 491-496

Abas, Z. W. Chng, L.P. \& Norziati, M. (2009) "A study on learner readiness for mobile learning at Open University Mal aysia", working paper

Corrin, L., Lockyer, L. \& Bennett, S. (2010) "Technological diversity: An investigation of students' technology use in everyday life and academic study", Learning, Media and Technology, vol. 35(4): 387-401

Donnelly, K. (2009) "Learning on the Move: How m-Learning Could Transform Training and Development", Development and Learning in Organizations, vol. 23(4): 8-11

Faff, R.W. (2015) "A Simple Template for Pitching Research", Accounting \& Finance, vol. 55, no. 2: 311-336

Faff, R. W. (2017) "Pitching Research", Available at SSRN: http://ssrn.com/abstract=2462059 or http://dx. doi.org/10.2139/ssrn.2462059.

Gikas, J.G. \& Grant, M.M. (2013) “Mobile Computing Devices in Higher Education: Student Perspectives on Learning with Cell phones, Smartphones \& Social Media", The Internet and Higher Education, vol. 19(October): 18-26

Herrington, A. \& Herrington, J. (2007) "Authentic mobile learning in higher education", available online at http://www.aareedu.au/publicationsdatabase php/5398/authentic-mobile-learning-in-higher-education

Liu, Y., Li, H. \& Carlsson, C. (2010) "Factors Driving the Adoption of $\mathrm{m}$ Learning: An Empirical Study", Computers \& Education, vol. 55(3): 1211-1219

Park, S. Y., Nam M. W. \& Cha, S. B. (2012) “University Students' Behavioral Intention to use Mobile Learning: Evaluating the Technology Acceptance Mode", British J ournal of Educational Technology, vol. 43(4): 592-605 
Pozzi, A. (2007) "The Impact of m-Learning in School Contexts: An "Inclusive" Perspective", Lecture Notes in Computer Science, vol. 4556: 748-755

Winters, N. (2006) "What is mobile learning?" In M. Sharples (Ed.), Big issues in mobile learning. Retrieved from http://matchsz.inf.eltehu/tt/docs/Sharples20062.pdf

Y eap, J. A., Ramayah, T. \& Soto-Acosta, P. (2016) "Factors propelling the adoption of mlearning among students in higher education", Electronic Markets, vol. 26(4): 323-338 